RAD Conference Proceedings, vol. 2, pp. 141-148, 2017

www.rad-proceedings.org

\title{
VARIABILITY OF INDOOR RADON LEVEL ACCUMULATION: A STUDY IN PORTUGUESE THERMAL SPAS
}

\author{
A.S. Silva1,2, M.L. Dinis ${ }^{1,2^{*}}$ \\ ${ }^{1}$ CERENA, FEUP/UPorto - Centre for Natural Resources and the Environment, \\ Faculty of Engineering, University of Porto, R. Dr. Roberto Frias, 4200-465, Porto, Portugal \\ ${ }^{2}$ PROA/LABIOMEP - Research Laboratory on Prevention of Occupational and Environmental Risks, \\ Faculty of Engineering, University of Porto, R. Dr. Roberto Frias, 4200-465, Porto, Portugal
}

\begin{abstract}
The aim of this work was to measure the concentration of the indoor radon in 16 Portuguese thermal spas (38\% of the thermal spas in Portugal) and assess its variability within each establishment as well as its contribution to the effective dose. The measurements were performed with $C R-39$ passive detectors placed at different workplaces within each thermal spa, for an average period of 42 days, in different seasons of the year. The indoor radon concentrations ranged from 68 to $4335 \mathrm{~Bq} / \mathrm{m}^{3}$ with a geometric mean of $437 \mathrm{~Bq} / \mathrm{m}^{3}$ and an arithmetic mean of 702 $\mathrm{Bq} / \mathrm{m}^{3}$. Geological factors that can lead to such behaviour are discussed. The results showed that the EU reference level of $300 \mathrm{~Bq} / \mathrm{m}^{3}$ (Directive 2013/59/EURATOM) was exceeded in several cases. No significant differences were observed among measurements taken during different seasons of the year, however, large differences of radon concentrations in different rooms of the same thermal establishment were noted as well as significant difference when comparing to other thermal establishments. The effective dose resulting from the inhalation of radon ranged between 2 and $32 \mathrm{mSv} / \mathrm{y}$. In $43 \%$ of the thermal spas, the effective dose is likely to be higher than $6 \mathrm{mSv} / \mathrm{y}$, which means that the exposure should be managed as a "planned exposure situation" according to the European Directive 2013/59/EURATOM. Also, in 19\% of the cases, the annual effective dose exceeds $20 \mathrm{mSv} / \mathrm{y}$, and in these cases, monitoring and radiological protection is required as laid down in the European Directive 2013/59/EURATOM.
\end{abstract}

Key words: Radon, effective dose, geology, thermal spa

DOI: $10.21175 /$ RadProc.2017.29

\section{INTRODUCTION}

Exposure to ionizing radiation of natural origin contributes with $81 \%$ to the annual dose received by the population, and, in the case of Portugal, most of the average annual dose to which the population is exposed by natural sources is due to radon inhalation and its radioactive progeny (57\%), and terrestrial gamma radiation (18\%) [1].

Radon is currently recognized as the leading cause of lung cancer, with the exception of tobacco $[2,3,4,5$, $6,7]$.

The exposure to radon and its decay products occurs predominantly in indoor environments like dwellings and workplaces. Most of the radon in indoor air comes from soil underneath the buildings. Radon can also dissolve and accumulate in water from underground sources such as wells and springs. When water that contains radon is used, radon gas escapes from the water and goes into the indoor air. In general, radon is present in the outdoor air in small amounts and it is quickly diluted to very low concentrations. In confined spaces such as basements and subterranean spaces, radon may be present in higher concentrations, in particular, in cases where ventilation is deficient or non-existent.

The main workplaces where the exposure to radon can be considered as occupational exposure are mines and other underground workplaces such as caves and galleries (where high concentrations of radon are accumulated) and thermal spas (exposure through use and handling of thermal water) [8].

The health hazards from radon are mainly due to the inhalation of airborne activity (unattached and attached) of radon decay products. The most important parameters affecting the inhalation dose resulting from these decay products are aerosol size distribution, unattached fraction, breathing rate, and the depth in tissue of the target cell nuclei [9, 10, 11].

Radon concentration varies considerably depending on different parameters: i) source term (topography, soil characteristics, type of dwelling); ii) environmental parameters (temperature, pressure, humidity, wind speed, weather) and iii) other variables such as routine habits and lifestyle of the population.

For indoor radon, the source terms are represented by: soil beneath the buildings, construction materials and water $[11,12]$. The soil type, altitude, and

\footnotetext{
*mldinis@fe.up.pt
} 
geological formation strongly affect the indoor and outdoor doses $[11,13]$. For the same region, the indoor radon concentration may be affected by the variation of the construction materials used for building while other factors remain constant (such as pressure differential, weather and climate, etc.) $[11,14]$. At the same time, routine habits and lifestyle of the population may be very different, which makes it extremely difficult to relate all the parameters, quantify and interpret the variability of indoor radon concentration.

In Portugal, the geological settings are mostly comprised of granite rocks with uranium mineralization, which represents an elevated risk for high indoor radon levels, particularly in some specific regions. Therefore, in the national legislation, DL 79/2006 [15], the reference value for the maximum indoor radon concentration within the existing buildings is defined $\left(400 \mathrm{~Bq} / \mathrm{m}_{3}\right)$, being monitored mandatorily only in dwellings located in granitic areas [16]. Also, Portugal has a long tradition of hydrotherapy therapeutics with mineral water from the occurrences of natural springs, which outcrop, in many cases, from faulty and joins with uranium mineralizations. Therefore, there is a high probability of significant amounts of radon to be present in mineral waters used for therapeutic treatments.

The European Union, through the Directive 96/29/EURATOM [17], identified hydrotherapy as a professional activity during which workers are exposed to radiation from natural sources. Moreover, in the recently published European Directive 2013/59/EURATOM, it is defined that the reference level for the annual average activity concentration in air should not be higher than $300 \mathrm{~Bq} / \mathrm{m} 3$, unless it is warranted by national prevailing circumstances, being implicit that, in this case, the Member State submits the information to the European Commission.

In what concerns the effective doses, the Directive 2013/59/EURATOM also refers that, where exposure of workers is likely to exceed the effective dose of 6 $\mathrm{mSv} /$ year, it should be managed as a "planned exposure scenario" where dose and dose restriction limits (exposure optimization) apply and case The effective dose is equal to or less than $6 \mathrm{mSv} /$ year, the company is required to maintain the exposure of the workers under observation [16].

The aim of this work was to assess the exposure to indoor radon by measuring the concentration of the indoor radon in 16 Portuguese thermal spas (38\% of the thermal spas in Portugal) and evaluate its variability within each establishment as well as its contribution to the effective dose. Geological factors that can affect the indoor radon levels, and consequently the annual effective dose, are discussed.

\section{MAterials AND MEthodS}

\subsection{Study area}

The Portuguese mainland, located in western Iberia, presents three fundamental units, distinct from the chronological point of view, and from the structure of land. These morpho-structural units are: i) Hesperic Massif; (ii) Meso-Cenozoic Occidental and Meridional Basins and (iii) Tejo and Sado Basins.

The great diversity of the geology characteristic of the country (in the north, abound granite and other plutonic rocks, in the centre and south, schist, limestone, sandstone and quartzite) determines the different physical-chemical composition of Portuguese mineral water and therefore, the occurrences of thermal waters have considerably different characteristics. In general, the geothermal potential is directly related to the tectonic features, which beneficiate the circulation of the fluids.

In what concerns the Hesperic Massif, most of the thermal springs are preferably located along NNE, NE and ENE orientation alignments and associated with granitic and shale rocks, as well as rich quartzite minerals of sulfide mineralizations. These are essentially sulfuric waters, which are poorly mineralized, and some are bicarbonate and gasocarbonic, the latter having high mineralizations. Hyposaline waters seem to be correlated mainly with geological environments where quartzite rocks predominate.

In the Meso-Cenozoic Occidental Basin, the geology is dominated by extensive sedimentary formations. The thermal springs occur alongside the faults that originated from the typhonic valleys in areas of gypsum-saline diapiris. As a result, these waters are chlorate-bicarbonate-sodium, and the presence of sulphate-calcium hot springs is also noteworthy. These are hypersaline waters with $\mathrm{pH}$ values close to neutrality.

In the Meso-Cenozoic Meridional Basin, the thermal waters are essentially bicarbonate-sodic and bicarbonate-calcium, due to the interactions with igneous and sedimentary rocks, respectively.

This study was performed in 16 thermal spas (TS) located in the following districts: Aveiro (1 TS), Braga (3 TS), Bragança (1 TS), Castelo Branco (1 TS), Guarda (3 TS), Porto (2 TS), Viana do Castelo (1 TS), and Viseu (4 TS).

These eight districts are mainly located in the North/Center region of Portugal where most of the natural springs, with emergency temperatures between $20{ }^{\circ} \mathrm{C}$ and $76^{\circ} \mathrm{C}$, are located (Fig. 1).

In what concerns the geological characteristics of the regions where, in particular, the studied thermal spas are located (obtained from the geological maps of Portugal), $69 \%(11 / 16)$ of the TS are located mostly in granitic regions, $25 \%(4 / 16)$ in regions with granite and schist substrate and $6 \%(1 / 16)$ in a region of metasediment rocks (Table 1 ).

For lithology, and in particular in what concerns uranium and thorium mineralizations, only one Portuguese geological map (Viseu 17A - where TS6 and $\mathrm{TS}_{3}$ are located) presents data for these mineral occurrences. For the local region where TS6 is located, ${ }^{40} \mathrm{~K},{ }^{235 \mathrm{U}}$ and ${ }^{232} \mathrm{Th}$ occur with concentrations of $40800 \pm 20.4 \mathrm{ppm} ; 1260 \pm 1.2 \mathrm{ppm}$, and $7.4 \pm 1.2 \mathrm{ppm}$, respectively [22], while for the local region where TS3 is located, these values are: $46600 \pm 1530 \mathrm{ppm}, 118 \pm 7.1$ ppm and $9.4 \pm 1.0 \mathrm{ppm}$, respectively. 


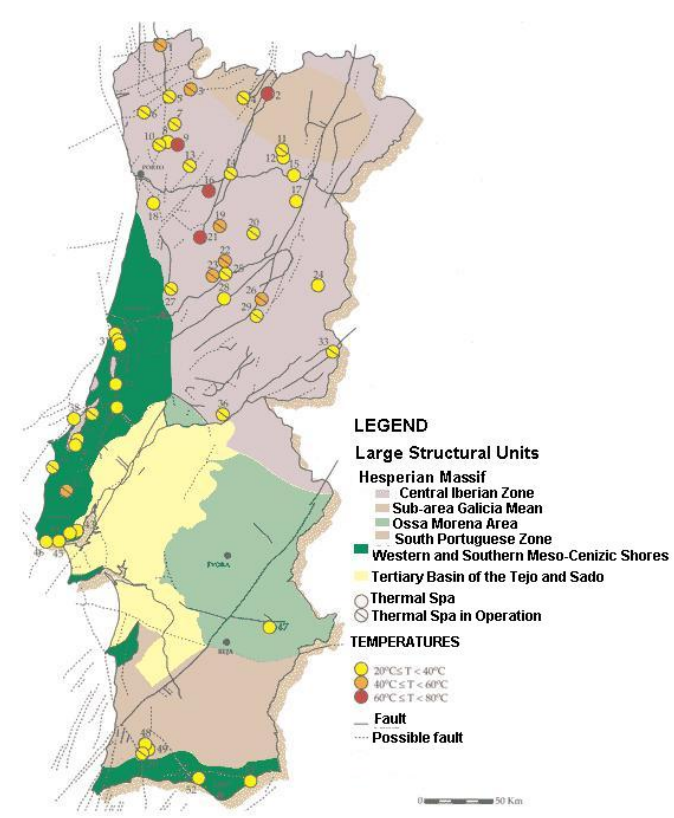

Figure 1. Thermal spas in Portugal

Table 1. Geological structure of the regions where the studied thermal spas are located

\begin{tabular}{|c|c|c|c|c|}
\hline TS & $\begin{array}{c}\text { Geological } \\
\text { map } \\
(1: 5000)\end{array}$ & $\begin{array}{c}\text { Geological } \\
\text { information }\end{array}$ & $\begin{array}{c}\text { Structure of } \\
\text { the Massif }\end{array}$ & $\begin{array}{c}\text { Type of } \\
\text { ventilation }\end{array}$ \\
\hline TS1 & 16B [18] & $\begin{array}{l}\text { Metasediment } \\
\text { Rocks }\end{array}$ & $\begin{array}{c}\text { Fault } \\
\text { Intersection }\end{array}$ & NV/MV \\
\hline TS2 & 17A [19] & $\begin{array}{c}\text { Granite and } \\
\text { Schist Substrate }\end{array}$ & $\begin{array}{c}\text { Penacova- } \\
\text { Régua-Verin }\end{array}$ & $\mathrm{NV} / \mathrm{MV}$ \\
\hline $\mathrm{TS} 3$ & $17 \mathrm{C}[20]$ & $\begin{array}{c}\text { Granite } \\
\text { Substrate }\end{array}$ & -- & $\mathrm{NV} / \mathrm{MV}$ \\
\hline TS4 & $11 \mathrm{C}[21]$ & $\begin{array}{c}\text { Granite and } \\
\text { Schist Substrate }\end{array}$ & $\begin{array}{c}\text { Fracturing } \\
\text { dependency }\end{array}$ & NV \\
\hline $\mathrm{TS}_{5}$ & $17 \mathrm{~A}[19]$ & $\begin{array}{c}\text { Granite and } \\
\text { Schist Substrate }\end{array}$ & Rio Dão Fault & $\mathrm{NV} / \mathrm{MV}$ \\
\hline TS6 & $5^{B}$ [22] & $\begin{array}{c}\text { Granite } \\
\text { Substrate }\end{array}$ & $\begin{array}{c}\text { Fault } \\
\text { Intersection }\end{array}$ & $\mathrm{NV} / \mathrm{MV}$ \\
\hline TS7 & 5B [22] & $\begin{array}{c}\text { Granite } \\
\text { Substrate }\end{array}$ & $\begin{array}{c}\text { Fault } \\
\text { Intersection }\end{array}$ & NV \\
\hline TS8 & 13B [23] & $\begin{array}{c}\text { Granite } \\
\text { Substrate }\end{array}$ & $\begin{array}{c}\text { Fault } \\
\text { Intersection }\end{array}$ & $\mathrm{NV}$ \\
\hline TS9 & $20 B[24]$ & $\begin{array}{c}\text { Granite } \\
\text { Substrate }\end{array}$ & $\begin{array}{c}\text { Fault } \\
\text { Intersection }\end{array}$ & $\mathrm{NV}$ \\
\hline TS10 & $18 \mathrm{C}[25]$ & $\begin{array}{c}\text { Granite } \\
\text { Substrate }\end{array}$ & -- & $\mathrm{NV} / \mathrm{MV}$ \\
\hline TS11 & $20 B[24]$ & $\begin{array}{c}\text { Granite } \\
\text { Substrate }\end{array}$ & $\begin{array}{c}\text { Fault } \\
\text { Intersection }\end{array}$ & $\mathrm{NV}$ \\
\hline TS12 & $17 \mathrm{C}[20]$ & $\begin{array}{c}\text { Granite } \\
\text { substrate }\end{array}$ & $\begin{array}{c}\text { Fault } \\
\text { Intersection }\end{array}$ & $\mathrm{NV} / \mathrm{MV}$ \\
\hline $\mathrm{TS} 13$ & $15 \mathrm{~A}[26]$ & $\begin{array}{l}\text { Granite } \\
\text { Substrate }\end{array}$ & $\begin{array}{c}\text { Vilariça - } \\
\text { Manteigas } \\
\text { Fault }\end{array}$ & $\mathrm{NV} / \mathrm{MV}$ \\
\hline TS14 & $9 B$ [27] & $\begin{array}{c}\text { Granite } \\
\text { Substrate }\end{array}$ & $\begin{array}{c}\text { Fault } \\
\text { Intersection }\end{array}$ & $\mathrm{NV} / \mathrm{MV}$ \\
\hline TS15 & $5 \mathrm{D}[28]$ & $\begin{array}{c}\text { Granite } \\
\text { Substrate }\end{array}$ & $\begin{array}{c}\text { Fault } \\
\text { Intersection }\end{array}$ & $\mathrm{NV}$ \\
\hline TS16 & 1B [29] & $\begin{array}{c}\text { Granite and } \\
\text { Schist Substrate }\end{array}$ & $\begin{array}{l}\text { Rio Minho } \\
\text { Fault }\end{array}$ & NV \\
\hline
\end{tabular}

For the radiogenic potential of the region where TS6 is located, the concentrations of $U$ and Th are $7.4 \pm 1.2 \mathrm{ppm}$ and $20.4 \pm 1.2 \mathrm{ppm}$, respectively, while for $\mathrm{TS}_{3}$, the concentrations of $\mathrm{U}$ and Th are $8.5 \pm 1.4 \mathrm{ppm}$ and $12.1 \pm 3.9 \mathrm{ppm}$, respectively. The geological map of Viseu $17 \mathrm{~A}$ also shows that the radiogenic potential for the indoor air is considered high for both locations [22].

\subsection{Sampling plan}

The study was conducted during two sampling campaigns for radon concentration measurements and dose assessment. The first campaign was carried out between November 2013 and June 2014 and the second campaign took place between July 2014 and September 2015 .

In some thermal spas ( $\left.\mathrm{TS}_{4}, \mathrm{TS}_{5}, \mathrm{TS} 6, \mathrm{TS} 7\right)$ the measurements were carried out in a campaign, since they are open to the public for 4 months. In the case of the TS16 thermal spa, the measurements were only made in a campaign because the thermal spa closed to the public due to works.

Radon concentration in the indoor air of the thermal spas was measured in different spaces of permanence of workers: access corridor to the thermal pool (AC), buvete hall (BH), bathtubs (BT), hall spa (HS), jet shower (JS), ORL (inhalation techniques), treatment area (TA), thermal pool (TP), vapors (VP), vichy shower (VS), machines house (MH) in different seasons (spring/summer and autumn/winter) and, on average for a period of 42 days.

In order to proceed to the identification and characterization of the thermal spas, a questionnaire was filled during the first visit to the locality. The questionnaire is divided into 2 sections: i) identification and characterization of the conditions of the operation of the thermal spas and (ii) characterization of the installations.

The first section deals with issues related to work schedules, gender, seniority in the work place and number of thermalists per year.

The second section presents the criteria used for the characterization of thermal spa facilities, namely the existence of risk-assessment procedures, previous studies on the measurement of radon concentrations, the existence or nonexistence of a radiological control plan (RCP), safety services and health at work (SSHW), type of ventilation (natural ventilation (window opening) mechanical ventilation), presence of air conditioning, existence of sludge treatment and thermal pool. A survey for the description of the characteristics of the equipment used in therapeutic treatments was also included.

\subsection{Measurement methods}

The measurements of radon concentrations in the indoor air were performed using CR-39 nuclear track detectors (5-cm height, $3-\mathrm{cm}$ diameter) enclosed in small cylindrical diffusion chambers (Fig. 2). These detectors comprise a small piece of polycarbonate, highly sensitive to ionizing particle tracks such as alpha particles [30].

The CR-39 detectors were placed approximately 2 meters from the floor. At the end of each time period (on average 42 days), the detectors were removed and stored individually in sealed containers to prevent any contamination from other sources during transport to the laboratory [31]. The analysis was performed in the Natural Radioactivity Laboratory in the Department of Earth Sciences of the University of Coimbra.

The Laboratory of Natural Radioactivity of the Department of Earth Sciences of the University of 
Coimbra regularly participates in comparison exercises with other laboratories in order to estimate the statistical uncertainty (analytical error of less than 10\% of the value obtained). The limit of detection using the described procedure is $5 \mathrm{~Bq} / \mathrm{m}^{3}$.

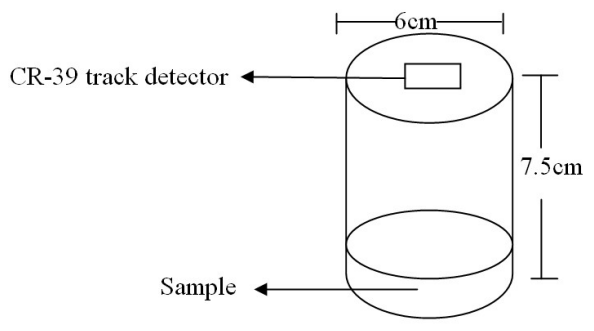

Figure 2. CR-39 nuclear track detectors

The inhalation dose (D, mSv/y) was calculated from the results obtained for the indoor radon concentration $\left(C R n, \mathrm{~Bq} / \mathrm{m}^{3}\right)$ and considering the following exposure parameters in indoor environments (ICRP, 1994; UNSCEAR, 2000) (Eq. 1): for the exposure time (ET), an occupancy of $2000 \mathrm{~h} / \mathrm{y}$ for the exposure within the thermal spas, an equilibrium factor between radon and its progeny of 0.4 and a dose conversion factor of $9 \times 10^{-6}\left(\mathrm{mSv} / \mathrm{y}\right.$ per $\left.\mathrm{Bq} / \mathrm{m}^{3}\right)$ (effective dose received by adults per unit of ${ }^{222} \mathrm{Rn}$ activity per unit of air volume).

$$
D=C R n \times 0.4 \times E T \times 9 \times 10^{-6}
$$

Although there is job rotation in all the thermal spas (with the exception of TS8), the dose was assessed considering the "worst-case scenario", assuming that workers do not have job rotation. Therefore, the dose was calculated with the most conservative value of each input [30], meaning that a hypothetical situation was considered in which everything that contributes to the exposure was maximized, namely the exposure time $(2000 \mathrm{~h} / \mathrm{y})$ and indoor radon concentration (maximum value) [32].

The dose assessment was considered only for workers whose exposure will be reflected in a longterm impact (longer and continuous exposure) while patients or spa users will experience a short-term impact, probably once in a lifetime and negligible.

\section{RESULTS AND DISCUSSION}

\subsection{Indoor radon concentration}

Radon concentration values in thermal spas ranged from $73 \mathrm{~Bq} / \mathrm{m}^{3}$ to $4335 \mathrm{~Bq} / \mathrm{m}^{3}$. The highest value was obtained in $\mathrm{TS} 4$ and the minimal value was obtained in TS11 (Table 2).

By analyzing the Table 3 , the values of radon concentration in the indoor air of the thermal spas TS1, TS2 (winter), TS3, TS4, TS5, TS6, TS7, TS10 (winter and autumn), TS12, TS14 (winter), TS15 and TS16 exceed the $300 \mathrm{~Bq} / \mathrm{m}^{3}$ projected in the European Directive $2013 / 59 /$ EURATOM. In only $25 \%$ of thermal spas, the radon concentration in indoor air is less than $300 \mathrm{~Bq} / \mathrm{m}^{3}$ : TS8, TS9, TS11 and TS14.

In the thermal spas TS1, TS2, TS10, TS12, TS15 and TS16, the values obtained for the radon concentration in the indoor air in winter/autumn and spring/summer seasons are due to poor ventilation on the premises and it is assumed that radon predominantly originates from the subsoil, as these thermal spas are located in regions with granite substrate.

On the other hand, in $\mathrm{TS}_{3}$, the values of the indoor radon concentration, obtained in spring and summer, are very similar.

In $\mathrm{TS}_{4}$ it can be observed that radon concentration in indoor air is quite high, which is explained by the geological conditions, since this thermal spa is located in a predominantly granitic zone.

However, in $\mathrm{TS}_{5}$ it is assumed that the strong contribution of radon is from the thermal water, since the values of radon concentration in the water are quite high, and since in these places mineral water is used for therapeutic treatments.

Within TS6, the great difference in the values obtained for radon levels in the existing treatment rooms is due to the insufficient ventilation in some places, namely in the JS. 
Table 2. Indoor radon concentration $\left(\mathrm{Bq} / \mathrm{m}^{3}\right)$ in the studied thermal spa

\begin{tabular}{|c|c|c|c|c|c|c|c|c|c|}
\hline \multirow{2}{*}{ TS } & \multirow{2}{*}{ Location } & \multicolumn{2}{|c|}{ WI } & \multicolumn{2}{|c|}{ SP } & \multicolumn{2}{|c|}{ SU } & \multicolumn{2}{|c|}{$\mathbf{A U}$} \\
\hline & & ${ }^{222} \mathrm{Rn}$ & AV & ${ }^{222} \mathbf{R n}$ & AV & ${ }^{222} \mathbf{R n}$ & AV & ${ }^{222} \mathrm{Rn}$ & AV \\
\hline \multirow[t]{3}{*}{ TS1 } & \multirow{3}{*}{$\begin{array}{l}\text { BT } \\
\text { ORL } \\
\text { TP }\end{array}$} & 674 & \multirow[t]{3}{*}{1646} & -- & \multirow[t]{3}{*}{--} & 436 & \multirow[t]{3}{*}{1296} & -- & \multirow[t]{3}{*}{--} \\
\hline & & 3479 & & -- & & 3119 & & -- & \\
\hline & & 784 & & -- & & 333 & & -- & \\
\hline \multirow[t]{5}{*}{ TS2 } & $\mathrm{AC}$ & 566 & 566 & -- & -- & -- & 237 & -- & \\
\hline & ORL & 329 & & -- & & 187 & & -- & \\
\hline & TA & 692 & & -- & & -- & & -- & \\
\hline & TP & 517 & & -- & & 267 & & -- & \\
\hline & VS & 724 & & -- & & 258 & & -- & \\
\hline TS3 & ORL & -- & -- & 502 & 413 & 489 & 442 & -- & -- \\
\hline & $\mathrm{TA}$ & -- & & 401 & & 429 & & -- & \\
\hline & TP & -- & & 274 & & 333 & & -- & \\
\hline & VP & -- & & 453 & & 465 & & -- & \\
\hline & VS & -- & & 437 & & 495 & & -- & \\
\hline TS4 & ORL & -- & -- & -- & -- & 4335 & 3124 & -- & -- \\
\hline & VS & -- & & -- & & 1912 & & -- & \\
\hline TS5 & ORL & -- & -- & -- & -- & 1190 & 1256 & -- & -- \\
\hline & $\mathrm{RB}$ & -- & & -- & & 953 & & -- & \\
\hline & $\mathrm{SH}$ & -- & & -- & & 878 & & -- & \\
\hline & $\mathrm{TP}$ & -- & & -- & & 2181 & & -- & \\
\hline & VP & -- & & -- & & 1173 & & -- & \\
\hline & VS & -- & & -- & & 1163 & & -- & \\
\hline TS6 & $\mathrm{BH}$ & -- & -- & -- & -- & 1615 & 1047 & -- & -- \\
\hline & JS & -- & & -- & & 1681 & & -- & \\
\hline & ORL & -- & & -- & & 366 & & -- & \\
\hline & $\mathrm{TP}$ & -- & & -- & & 423 & & -- & \\
\hline & VS & -- & & -- & & 1148 & & -- & \\
\hline TS7 & ORL & -- & -- & -- & -- & 347 & 354 & -- & -- \\
\hline & VS & -- & & -- & & 361 & & -- & \\
\hline TS8 & ORL & -- & -- & 169 & 273 & -- & -- & 143 & 252 \\
\hline & VS & -- & & 376 & & -- & & 360 & \\
\hline TS9 & ORL & -- & -- & 169 & 232 & -- & -- & 269 & 234 \\
\hline & TP & -- & & 121 & & -- & & 204 & \\
\hline & VS & -- & & 406 & & -- & & 229 & \\
\hline TS10 & $\mathrm{AC}$ & 641 & 705 & -- & 255 & -- & & 209 & 312 \\
\hline & LP & 1079 & & -- & & -- & & 377 & \\
\hline & ORL & -- & & 255 & & -- & & -- & \\
\hline & TA & 481 & & -- & & -- & & 305 & \\
\hline & $\mathrm{TP}$ & 618 & & -- & & -- & & 358 & \\
\hline TS11 & HS & -- & -- & 116 & 153 & -- & -- & 132 & 222 \\
\hline & ORL & -- & & 312 & & -- & & 498 & \\
\hline & $\mathrm{TP}$ & -- & & 73 & & -- & & 101 & \\
\hline & VS & -- & & 112 & & -- & & 155 & \\
\hline TS12 & JS & -- & & 1130 & 1608 & -- & -- & -- & 2441 \\
\hline & ORL & -- & & 2298 & & -- & & 1643 & \\
\hline & $\mathrm{TA}$ & -- & & 1145 & & -- & & -- & \\
\hline & $\mathrm{TP}$ & -- & & 1494 & & -- & & 2808 & \\
\hline & VS & -- & & 1971 & & -- & & 2873 & \\
\hline TS13 & ORL & -- & -- & 146 & 147 & -- & -- & 235 & 184 \\
\hline & $\mathrm{TP}$ & -- & & 203 & & -- & & 176 & \\
\hline & VS & -- & & 93 & & -- & & 141 & \\
\hline TS14 & BT & 172 & 356 & -- & -- & 266 & 219 & -- & -- \\
\hline & ORL & 375 & & -- & & 175 & & -- & \\
\hline & SA & 467 & & -- & & 214 & & -- & \\
\hline & $\mathrm{TP}$ & 370 & & -- & & 240 & & -- & \\
\hline & VP & 398 & & -- & & 199 & & -- & \\
\hline TS15 & ORL & 707 & 580 & -- & -- & -- & -- & -- & -- \\
\hline & $\mathrm{TP}$ & 355 & & -- & & -- & & -- & \\
\hline & $\mathrm{AC}$ & 841 & & -- & & -- & & -- & \\
\hline & $\mathrm{MH}$ & 422 & & -- & & -- & & -- & \\
\hline TS16 & MH & 1692 & 1122 & -- & & -- & & -- & \\
\hline & $\mathrm{TP}$ & 862 & & -- & & -- & & -- & \\
\hline
\end{tabular}


In TS7, TS8 and TS9, TS11, TS13, TS14 the values obtained in the different locations are very similar and close to the limit required by the legislation.

On the other hand, it is in the ORL that the values of radon concentration in the indoor air of the thermal spas tend to be high (Table 2 and Fig. 3). However, the values of radon concentration in the indoor air tend to be lower in the AC (figure 3).

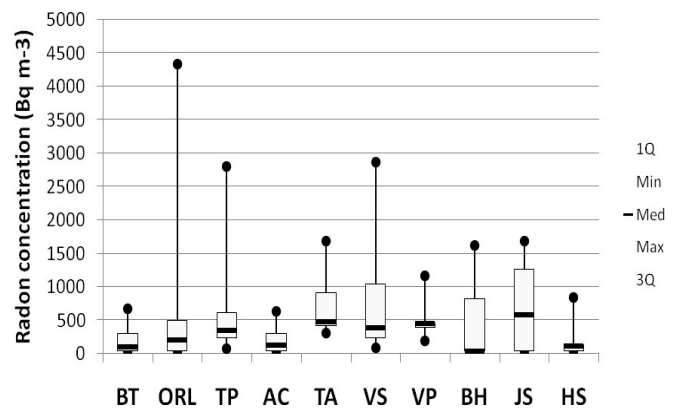

Figure 3. Concentration of radon in indoor air by location

It is also verified that radon levels are significantly higher in the winter months, since due to the heating of the rooms, the hot air rises, creating a negative pressure in the lower floors and this thermal effect leads to the suction of radon from the ground to the building and also because spaces are less ventilated during the winter (Fig. 4).

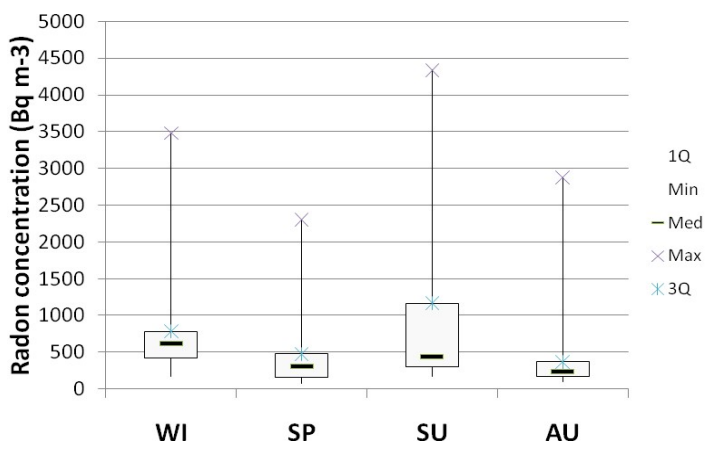

Figure 4. Radon concentration in indoor air versus seasons of the year

\subsection{Dose assessment}

The values of the annual effective dose ranged between $1.21 \mathrm{mSv} / \mathrm{y}$ and $31.21 \mathrm{mSv} / \mathrm{y}$. In general, the annual effective dose is below $6 \mathrm{mSv} / \mathrm{y}$, with the exception of TS1, TS4, TS5 (ORL), TS10 (LP) and TS12 (TP) (Fig. 5).

The highest value was obtained in $\mathrm{TS}_{4}$ in the ORL, while the lowest value was obtained in TS8 also in the ORL.

According to the new Directive 2013/59/Euratom, workers from thermal spa establishments are facing a planned exposure situation where dose limits apply. In all other cases, where the effective dose is equal to or less than $6 \mathrm{mSv} / \mathrm{y}$, it is required to keep the exposure under observation.

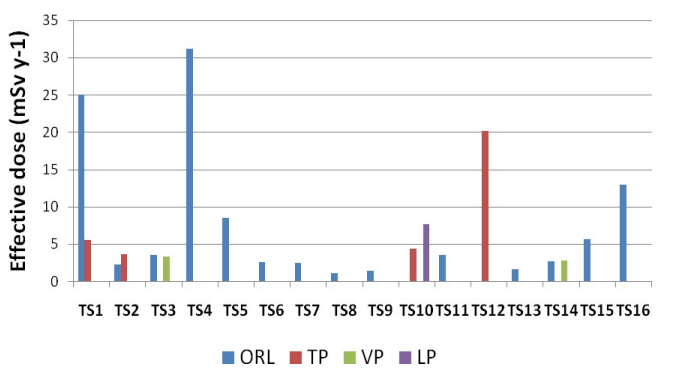

Figure 5. Effective dose by thermal spa

\section{CONCLUSION}

In $88 \%$ of the results, the indoor radon concentration is above the reference level recommended by the EU. The main reason for these results is due to the geological setting where the thermal spas are located, namely in a granitic region.

Despite the geological (predominantly granitic) condition, in $18 \%$ of thermal spas the levels of radon concentration in indoor air were below the reference levels recommended by the EU. This may be justified by the effective ventilation system inside the thermal spa (mechanical ventilation system). Generally, the main source of the radon is the soil but in some cases the construction materials can be also the main source.

In most thermal spas, the highest results of radon concentration in indoor air were obtained during the winter period because the spaces are less ventilated during this period.

It can be seen that in $50 \%$ of the thermal spas (TS2, TS4, TS5, Ts10, TS11, TS12, TS15 and TS16) there is a great variability of the values of the radon concentration in indoor air. This is due to the ventilation conditions of the different spaces and it is assumed that radon originates from the subsoil and/or building materials due to the geological setting where these thermal spas are located.

In $31 \%$ of the thermal spas, the annual effective dose is higher than $6 \mathrm{mSv} / \mathrm{y}$, which is the reason why it is necessary to maintain the effective annual dose of the workers under observation. However, in $39 \%$ of thermal spas, workers face a situation of planned exposure.

\section{REFERENCES}

1. Radão - um gás radioativo de origem natural, Instituto Tecnológico e Nuclear, Lisboa, Portugal, 2010. (Radon - a radioactive gas of natural origin, Technological and Nuclear Institute, Lisbon, Portugal, 2010.)

Retrieved from:

http://www.itn.pt/docum/relat/radao/itn gas radao. pps

Retrieved on: Dec. 20, 2016 
2. "Sources and effects of ionizing Radiation," United Nations Scientific Committee on the Effects of Atomic Radiation, New York (NY), USA, Rep. 46 (A/55/46), 2000.

Retrieved from:

http://www.unscear.org/docs/publications/2000/UNS CEAR 2000 Report Vol.I.pdf

Retrieved on: Dec. 20, 2016

3. Cadernos da Direcção-Geral da Saúde, vol. 1, Lisboa, Portugal: Direcção-Geral da Saúde, 2002. (Notebooks of Directorate-General for Health, vol. 1, Lisbon, Portugal: Directorate-General for Health, 2002.)

Retrieved from:

https://www.dgs.pt/upload/membro.id/ficheiros/ioo5 519.pdf

Retrieved on: Dec. 14, 2016

4. "Radiation Protection against Radon in Workplaces other than Mines," IAEA and ILO, Vienna, Austria, Rep. 33, 2003.

Retrieved from:

http://www-

pub.iaea.org/MTCD/publications/PDF/Pub1168 web. pdf

Retrieved on: Dec. 14, 2016

5. Radon and health, WHO, Geneva, Switzerland, 2007. Retrieved from: http://www.who.int/mediacentre/factsheets/fs291/en/ Retrieved on: Dec. 14, 2016

6. Handbook of indoor radon: A public health perspective, WHO, Geneva, Switzerland, 2009.

Retrieved from:

http://apps.who.int/iris/bitstream/10665/44149/1/97 89241547673 eng.pdf Retrieved on: Dec. 14, 2016

7. Consumer's Guide to Radon Reduction: How to fix your home, United States Environmental Protection Agency, Washington (DC), USA, 2016.

Retrieved from:

https://www.epa.gov/sites/production/files/201612/documents/2016 consumers guide to radon red uction.pdf

Retrieved on: Dec. 14, 2016

8. J. Nikolov, N. Todorović, I. Bikit et al., "Radon in thermal waters in south-east part of Serbia," Radiation Protection Dosimetry, vol. 160, no. 1-3, pp. 239 - 243, Jul. 2014.

DOI: $10.1093 / \mathrm{rpd} / \mathrm{ncuo94}$

PMid: 24707000

9. A. Kumar, R. P. Chauhan, M. Joshi, P. Aggarwal, "Implications of variability in Indoor radon/thoron levels: a study of dwellings in Haryana, India," Environ. Earth. Sci., vol. 73, no. 8, pp. 4033 - 4042, 2015. DOI: $10.1007 / \mathrm{s} 12665-014-3688-5$

10. G. M. Kendall, T. J. Smith, "Doses to organs and tissues from radon and its decay products," J. Radiol. Prot., vol. 22, no. 4, pp. 389 - 406, Dec. 2002. DOI: $10.1088 / 0952-4746 / 22 / 4 / 304$ PMid: 12546226

11. F. Lamonaca, V. Nastro, A. Nastro, D. Grimaldi, "Monitoring of indoor radon pollution," Measurement, vol. 47, pp. 228 - 233, Jan. 2014. DOI: 10.1016/j.measurement.2013.08.058

12. M. S. Khan, D. S. Srivastav,a, A. Aza, "Study of radium content and radon exhalation rates in soil samples of northern India," Environ. Earth Sci., vol. 67, no. 5, pp. $1363-1371,2012$. DOI: $10.1007 / \mathrm{s} 12665-012-1581-7$

13. V. Meht, A. Kumar, S. P. Singh, R. P. Chauhan, G. S. Mudaha,r, "Measurement of indoor radon, thoron and their progeny levels in dwellings of Union Territory Chandigarh, India: correlation with radon exhalation rates," Rom. J. Phys., vol. 59, no. 7-8, pp. $834-845$, 2014.
Retrieved from:

http://www.nipne.ro/rjp/2014 59 7-

8/0834 0845.pdf

Retrieved on: Dec. 14, 2016

14. A. S. Silva, M. L. Dinis, A. J. S. C. Pereira, "Assessment of indoor radon levels in Portuguese thermal spas," in Proc. Conf. RAD 2015, Budva, Montenegro, 2015, pp. $331-335$.

Retrieved from:

http://www.rad-

conference.org/helper/download.php?file=../pdf/Proce edings\%20RAD\%202015.pdf

Retrieved on: Dec. 15, 2016

15. Ministério das Obras Públicas, Transportes e Comunicações. (4.4.2006). Decreto-Lei n. ${ }^{\circ}$ 79/2006. (Ministry of Public Works, Transport and Communications. (Apr. 4, 2006). Law-Decree no. 79/2006. )

Retrieved from:

https://www.bosch-certificacaoenergetica.pt/files/201208131407270.RSECE DL79 2 006.pdf

Retrieved on: Dec. 15, 2006

16. A. S. Silva, M. L. Dinis, "Measurements of indoor radon and total gamma dose rate in Portuguese thermal spas," in Occupational Safety and Hygiene IV, P. Arezes, J. S. Baptista, M. Barroso, P. Carneiro, P. Cordeiro, N. Costa, R. Melo, A. S. Miguel, G. Perestrelo, Eds., London, UK: Taylor \& Francis, 2016, ch. 92, pp. 485 489.

DOI: $10.1201 / \mathrm{b} 21172-93$

17. The Council of European Union. (May 13, 1996). Council Directive 96/29/EURATOM Laying down safety standards for the protection of the health of workers and the general public against the dangers arising from ionizing radiation.

Retrieved from:

http://eur-lex.europa.eu/legalcontent/EN/TXT/PDF/?uri=CELEX:31996Lo029\&fro $\underline{\mathrm{m}}=\mathrm{EN}$

Retrieved on: Dec. 15, 2016

18. C. Teixeira, A. C. Medeiros, A. P. Fernandes, "Notícia Explicativa da Carta Geológica de Portugal Folha 16-B, escala 1/ 50 ooo," Instituto Geológico e Mineiro, Lisboa, Portugal, 1969. (C. Teixeira, A.C. Medeiros, A. P. Fernandes, "Explanatory Notice of the Geological Chart of Portugal, Sheet 16-B, scale 1/50 ooo," Institute of Geology and Mining, Lisbon, Portugal, 1969.)

19. N. Ferreira, P. Castro, "Notícia Explicativa da Carta Geológica de Portugal, Folha 17-A (Viseu), escala 1/ 50 ooo," Instituto Geológico e Mineiro, Lisboa, Portugal, 2009. (N. Ferreira, P. Castro, "Explanatory Notice of the Geological Chart of Portugal, Sheet 17-A (Viseu), scale 1/50 ooo," Institute of Geology and Mining, Lisbon, Portugal, 2009.)

20. C. Teixeira, L. H. B. Carvalho et al., "Notícia Explicativa da Carta Geológica de Portugal, Folha 17-C (Santa Comba Dão), escala 1/ 50 ooo," Serviços Geológicos de Portugal, Lisboa, Portugal, 1961. (C. Teixeira, L. H. B. Carvalho, "Explanatory Notice of the Portuguese Geological Chart, Sheet 17-C (Santa Comba Dão), scale 1/50 00o," Geological Services of Portugal, Lisbon, Portugal, 1961.)

21. A. F. Silva, J.A. Rebelo, M. L. Ribeiro, "Notícia Explicativa da Carta Geológica de Portugal, Folha 11-C (Torre de Moncorvo), escala 1/ 50 ooo," Instituto Geológico e Mineiro, Lisboa, Portugal, 1988. (A. F. Silva, J. A. Rebelo, M. L. Ribeiro, "Explanatory Notice of the Geological Chart of Portugal, Sheet 11-C (Torre de Moncorvo), scale 1/50 0oo," Institute of Geology and Mining, Lisbon, Portugal, 1988.)

22. C. Teixeira, A.C. Medeiros, J. T. Lopes, "Notícia Explicativa da Carta Geológica de Portugal, Folha 05-B 
(Ponte da Barca), escala 1/ 50 ooo," Instituto Geológico e Mineiro. Lisboa, Portugal, 1974. (C. Teixeira, A. C. Medeiros, J. T. Lopes, "Explanatory Notice of the Geological Chart of Portugal, Sheet o5-B (Ponte da Barca), scale 1/50 0oo," Institute of Geology and Mining, Lisbon, Portugal, 1974.)

23. A. C. Medeiros, Notícia Explicativa da Carta Geológica de Portugal, Folha 13-B (Castelo de Paiva), escala 1/ 50 ooo," Instituto Geológico e Mineiro, Lisboa, Portugal, 1963. (A. C. Medeiros, "Explanatory Notice of the Geological Chart of Portugal, Sheet 13-B (Castelo de Paiva), scale 1/50 0oo," Institute of Geology and Mining, Lisbon, Portugal, 1963.)

24. C. Teixeira, H. Carvalho, J. P. Santos, "Notícia Explicativa da Carta Geológica de Portugal, Folha 20-B (Covilhã), escala 1/ 50 00o," Instituto Geológico e Mineiro, Lisboa, Portugal, 1975. (C. Teixeira, H. Carvalho, J. P. Santos, "Explanatory Notice of the Geological Chart of Portugal, Sheet 20-B (Covilhã), scale 1/50 00o," Institute of Geology and Mining, Lisbon, Portugal, 1975.)

25. C. Teixeira, J. A. Martins, A. C. Medeiros, L Pilar, L. P. Mesquita, M. N. Ferro, A. Rocha, "Notícia Explicativa da Carta Geológica de Portugal, Folha 18-C (Guarda), escala 1/ 50 ooo," Serviços Geológicos de Portugal, Lisboa, Portugal, 1963. (C. Teixeira, J. A. Martins, A. C. Medeiros, L. Pilar, L. P. Mesquita, M. N. Ferro, A. Rocha, "Explanatory Notice of the Portuguese Geological Chart, Sheet 18-C (Guarda), scale 1/50 00o," Geological Services of Portugal, Lisbon, Portugal, 1963.)

26. A. F. Silva, A. Ribeiro, M. L. Ribeiro, "Notícia Explicativa da Carta Geológica de Portugal, Folha 15-A (Vila Nova da Foz Côa), escala 1/ 50 ooo," Instituto Geológico e Mineiro, Lisboa, Portugal, 1990. (A. F. Silva, A. Ribeiro, M. L. Ribeiro, "Explanatory Notice of the Geological Chart of Portugal, Sheet 15-A (Vila Nova da Foz Côa), scale 1/50 ooo," Institute of Geology and Mining, Lisbon, Portugal, 1990.)
27. M. M. Andrade, F. Noronha, A. Rocha, "Notícia Explicativa da Carta Geológica de Portugal, Folha 09-B (Guimarães), escala 1/ 50 ooo," Instituto Geológico e Mineiro, Lisboa, Portugal, 1986. (M. M. Andrade, F. Noronha, A. Rocha, "Explanatory Notice of the Geological Chart of Portugal, Sheet o9-B (Guimarães) scale 1/50 00o," Institute of Geology and Mining, Lisbon, Portugal, 1986.)

28. C. Teixeira, A. C. Medeiros, J. R. Macedo, "Notícia Explicativa da Carta Geológica de Portugal, Folha 5-D (Braga), escala 1/ 50 ooo," Serviços Geológicos de Portugal, Lisboa, Portugal, 1973. (C. Teixeira, A. C. Medeiros, J. R. Macedo, "Explanatory Notice of the Geological Chart of Portugal, Folha 5-D (Braga), scale 1/50 0oo," Geological Services of Portugal, Lisbon, Portugal, 1973.)

29. A. Moreira, "Notícia Explicativa da Carta Geológica de Portugal, Folha 01-B (Monção), escala 1/ 50 000," Instituto Geológico e Mineiro, Lisboa Portugal, 1985 (A. Moreira, "Explanatory Notice of the Geological Chart of Portugal, Sheet 01-B (Monção), scale 1/50 ooo," Institute of Geology and Mining, Lisbon, Portugal, 1985.)

30. A. S. Silva, M. L. Dinis, A. J. S. C. Pereira, "Assessment of indoor radon levels in Portuguese thermal spa," Radioprotection, vol. 51, no. 4, pp. 249 - 254, Oct-Dec. 2016.

DOI: 10.1051/radiopro/2016077

31. Standard Test Method for Radon in Drinking Water, ASTM D5072 - 09e1, 2009. DOI: $10.1520 / D 5072$

32. M. A. Jayjock, J. R. Lynch, D. I. Nelson, Risk Assessment Principles for Hygienist, Fairfax (VA), USA: AIHA Press, 2000. 